\title{
First-year sea ice melt pond fraction estimation from dual-polarisation C-band SAR - Part 2: Scaling in situ to Radarsat-2
}

\author{
R. K. Scharien ${ }^{1}$, K. Hochheim ${ }^{2}$, J. Landy ${ }^{2}$, and D. G. Barber ${ }^{2}$ \\ ${ }^{1}$ Department of Geography, University of Victoria, Victoria, British Columbia, Canada \\ ${ }^{2}$ Centre for Earth Observation Science, Faculty of Environment Earth and Resources, University of Manitoba, \\ Winnipeg, Manitoba, Canada
}

Correspondence to: R. K. Scharien (randy@uvic.ca)

Received: 19 December 2013 - Published in The Cryosphere Discuss.: 27 January 2014

Revised: 28 September 2014 - Accepted: 3 October 2014 - Published: 25 November 2014

\begin{abstract}
Sea ice melt pond fraction $\left(f_{\mathrm{p}}\right)$, linked with lower sea ice surface albedo and increased light transmittance to the ocean, is inadequately parameterised in sea ice models due to a lack of observations. In this paper, results from a multiscale remote-sensing program dedicated to the retrieval of level first-year sea ice (FYI) $f_{\mathrm{p}}$ from dual co- and crosspolarisation C-band synthetic aperture radar (SAR) backscatter are detailed. Models which utilise the dominant effect of free-water melt ponds on the $\mathrm{VV} / \mathrm{HH}$ (vertical transmit and vertical receive/horizontal transmit and horizontal receive) polarisation ratio at high incidence angles are tested for their ability to provide estimates of the subscale $f_{\mathrm{p}}$. Retrieved $f_{\mathrm{p}}$ from noise-corrected Radarsat-2 quad-polarisation scenes are in good agreement with observations from coincident aerial survey data, with root mean square errors (RMSEs) of 0.05-0.07 obtained during intermediate and late stages of ponding. Weak model performance is attributed to the presence of wet snow and slush during initial ponding, and a synoptically driven freezing event causing ice lids to form on ponds. The $\mathrm{HV} / \mathrm{HH}$ (horizontal transmit and vertical receive/horizontal transmit and horizontal receive) ratio explains a greater portion of variability in $f_{\mathrm{p}}$, compared to $\mathrm{VV} / \mathrm{HH}$, when ice lids are present. Generally low HV channel intensity suggests limited applications using dual crosspolarisation data, except with systems that have exceptionally low noise floors. Results demonstrate the overall potential of dual-polarisation SAR for standalone or complementary observations of $f_{\mathrm{p}}$ for process-scale studies and improvements to model parameterisations.
\end{abstract}

\section{Introduction}

A decline in Arctic sea ice thickness over the past several decades (Kwok and Rothrock, 2009) has been linked in recent years to an ice cover dominated by thinner first-year ice (FYI), rather than thicker multi-year ice (MYI) (Kwok et al., 2009). During the summer melt season, FYI has a greater areal fraction of melt ponds, termed pond fraction $\left(f_{\mathrm{p}}\right)$, than MYI due to a relative lack of topographical controls on melt water flow (Fetterer and Untersteiner, 1998; Barber and Yackel, 1999; Eicken et al., 2002, 2004; Freitag and Eicken, 2003; Polashenski et al., 2012). Melt ponds have a lower albedo ( $\sim 0.2$ to 0.4$)$ compared to ice $(\sim 0.6$ to 0.8$)$ (Perovich, 1996; Hanesiak et al., 2001a), which promotes shortwave energy absorption into the ice volume and accelerates decay (Maykut, 1985; Hanesiak et al., 2001b). Accelerated heat uptake by pond-covered ice increases the rate at which its temperature related brine volume fraction increases to the point at which the fluid permeability threshold is crossed (Golden et al., 1998) and biogeochemical exchanges with the underlying ocean become possible (see Vancoppenolle et al., 2013, for a review). Light transmission to the underlying ocean occurs at an order of magnitude greater rate on pondcovered ice compared to bare ice (Inoue et al., 2008; Light et al., 2008; Ehn et al., 2011; Frey et al., 2011), which leads to ocean warming (Perovich et al., 2007) and stimulates underice primary production (Mundy et al., 2009; Arrigo et al., 2012). Ocean surface warming has been linked to subsequent reductions in seasonal ice volume due to its effect on the timing of seasonal melt onset and fall freeze-up (Laxon et al., 
2003; Perovich et al., 2007). Melt ponds promote the atmospheric deposition, and discharge into the ocean, of contaminants such as organochlorine pesticides (Pucko et al., 2012) and have higher nutrient concentrations (Lee et al., 2012).

Understanding the role of melt ponds in large-scale climatological and biogeochemical processes, improving weather forecast models and conducting climate-cryosphere process studies all introduce the challenge of upscaling field-based observations to regional and greater scales. Improvements to parameterisations of $f_{\mathrm{p}}$ have led to more comprehensive, physically based sea ice albedo schemes used in climate model simulations (Taylor and Feltham, 2004; Lüthje et al., 2006; Køltzow, 2007; Skyllingstad et al., 2009; Flocco et al., 2010) and greater understanding of ice-albedo feedbacks (Holland et al., 2012). However, parameterisations are based on limited field observations that do not account for the horizontal heterogeneity of ice types and $f_{\mathrm{p}}$. The $f_{\mathrm{p}}$ of an area comprising a mixture of FYI and MYI ice may vary from 10 to $70 \%$ at one time (Derksen et al., 1997; Eicken et al., 2004; Polashenski et al., 2012). Seasonal variations up to $50 \%$ on FYI are typical (Perovich and Polashenski, 2012), with variations $>75 \%$ observed on level FYI (Hanesiak et al., 2001a; Scharien and Yackel, 2005). Diurnal variations as high as $35 \%$ have been observed on level FYI (Scharien and Yackel, 2005).

Unmixing algorithms have been developed for estimating $f_{\mathrm{p}}$ from satellite multi-spectral optical data (Markus et al., 2003; Tschudi et al., 2008; Rösel et al., 2012). The approach by Rösel et al. (2012) facilitated a basin-scale analysis of $f_{\mathrm{p}}$ patterns using MODIS (Moderate Resolution Imaging Spectroradiometer) sensor data from 2000 to 2011 (Rösel and Kalschke, 2012). Optical data are limited by the persistent stratus cloud cover present in the Arctic during summer (Inoue et al., 2005), and retrieval algorithms are limited by assumptions made regarding the predefined spectral behaviour of subscale surface types open water, melt pond and snow/ice (Zege et al., 2012). Passive and active microwave radiometers and scatterometers provide synoptic estimations of timings related to pond formation, regardless of cloud cover and weather conditions (Comiso and Kwok, 1996; Howell et al., 2006). These data are potentially usable in large-scale models, though spatial resolutions of several kilometres, combined with signal contamination by land and open water (Heygster et al., 2012), make automated retrievals problematic.

Satellite synthetic aperture radar (SAR) is an all-weather, high-resolution active microwave data source capable of providing regional-scale sea ice information. Coupling between the physical and thermodynamic properties of seasonally evolving snow-covered sea ice, and SAR backscatter, is already well established from detailed in situ characterisations of ice electromagnetic properties and microwave interactions (e.g. Livingstone et al., 1987; Drinkwater, 1989; Barber, 2005; Perovich et al., 1998). Past studies focused mainly on backscatter measured at C-band frequency from
SARs ERS-1 and 2 (European Remote Sensing) (VV) and Radarsat-1 (HH). Backscatter was utilised for detection of the onset of advanced melt, also called ponding, the seasonal evolution of $f_{\mathrm{p}}$ and for proxy estimates of sea ice albedo (Winebrenner et al., 1994; Jeffries et al., 1997; Yackel and Barber, 2000; Yackel et al., 2001; Hanesiak et al., 2001b). However, single-polarisation backscatter during ponding is characterised by intensity variations spanning the entire observable range, as caused by surface wind-wave roughness variations on pond surfaces (Comiso and Kwok, 1996; Barber and Yackel, 1999; De Abreu et al., 2001). Importantly, accounting for variations is made more difficult by the subscale nature of ponds and bare ice patches relative to the resolution of spaceborne SARs. The launch of dual-polarisation and polarimetric SARs, such as Envisat-ASAR (Environmental Satellite Advanced Synthetic Aperture Radar) and Radarsat-2, has motivated research aimed at utilising the polarisation properties of backscatter, rather than intensity variations, for overcoming surface roughness limitations. Scharien et al. (2007) used the VV/HH ratio from C-band Envisat-ASAR data, demonstrating albedo estimates from pond-covered level FYI with greater accuracy using the ratio compared to single-polarisation backscatter. A strong $\mathrm{VV} / \mathrm{HH}$ with increasing incidence angle $(\theta)$ was found from in situ C-band polarimetric scatterometer measurements of ponds on level FYI (Scharien et al., 2012). This contrasted with no $\theta$ dependency of $\mathrm{VV} / \mathrm{HH}$ from bare ice, leading to the suggestion that $\mathrm{VV} / \mathrm{HH}$ is a function of the dielectric permittivity $\left(\varepsilon_{\mathrm{r}}\right)$ of free-water ponds in a manner consistent with the Bragg scattering theory. $\mathrm{VV} / \mathrm{HH}$ from a Bragg scattering surface is potentially important for pond information retrievals (timing of pond formation, $f_{\mathrm{p}}$ evolution and timing of pond drainage) since it is independent of surface roughness within the Bragg $k s<0.3$ validity region, defined by wave number $k$ and surface root mean square height $s$ (Fung, 1994). However, evidence from Scharien et al. (2012) of nonBragg scattering from strongly wind-roughened ponds, causing reductions in $\mathrm{VV} / \mathrm{HH}$, led to the conclusion that a more rigorous assessment of the roughness characteristics of ponds and bare ice, in relation to scattering theory, is needed.

In Part 1 of this study (Scharien et al., 2014; hereafter simply Part 1), surface roughness information pertinent to microwave-scattering models were derived from in situ wind-wave amplitude measurements of ponds, and highresolution elevation models of bare ice patches on level FYI in the Canadian Arctic. Bare ice was shown to fall within the Bragg region, while strongly wind-wave roughened ponds exceed the upper limit. The wind-speed (10 $\mathrm{m}$ height) range at which pond $s$ exceeds the Bragg limit at C-band frequency was established as $6.4-8.0 \mathrm{~m} \mathrm{~s}^{-1}$. A range was established to account for morphological factors such as whether or not pond orientation is favourable for wind-wave growth. Singlescattering integral equation model (IEM) theory, with a larger $k s<2$ validity range, was used to simulate the maximum variation in $\mathrm{VV} / \mathrm{HH}$ expected from pure ponds, e.g. $3.4 \mathrm{~dB}$ 
at $\theta=45^{\circ}$. The IEM is dependent on $s$ at all scales within its validity range and, as predicted by the Bragg model when $k s \geq 0.3$, dependence on $s$ causes $\mathrm{VV} / \mathrm{HH} \rightarrow 0 \mathrm{~dB}$ at a rate determined by the magnitude of $s$. Nevertheless, the detailed in situ data from Part 1 are not directly applicable to SAR. An evaluation of $\mathrm{VV} / \mathrm{HH}$ at the SAR scale is needed, given that footprints contain zones of heterogeneous roughness which is dependent on the relative fractions of ponds and ice, and environmental conditions. It is further suggested that $\mathrm{VV} / \mathrm{HH}$ be investigated for its utility in retrieving $f_{\mathrm{p}}$ rather than albedo, since C-band backscatter from ponds is purely surface scattering and independent from variations in pond albedo.

In this paper, Part 2, we extend the findings of Part 1 to the satellite SAR scale. Emphasis is placed on evaluating the utility of $\mathrm{VV} / \mathrm{HH}$ at large $\theta$ for retrievals of $f_{\mathrm{p}}$, though assessments of $\mathrm{VV}, \mathrm{HH}$ and $\mathrm{HV}$ and the $\mathrm{HV} / \mathrm{HH}$ ratio are included. This is achieved by combining quad-polarisation (quad-pol) Radarsat-2 (RS-2) imagery with coincident aerial photography (AP) partitioned into estimates of $f_{\mathrm{p}}$. Our specific research questions are (1) how do SAR measured Cband quad-pol backscatter parameters relate to stages of pond evolution on level FYI, and (2) can C-band VV/HH be used to effectively estimate $f_{\mathrm{p}}$ from level FYI?

A summary of melt pond evolutionary stages on FYI is given in Sect. 2. In Sect. 3.1 we describe the study site, the AP equipment and survey plan, the RS- 2 data set and colocated in situ data. This is followed by a description of the procedure used for partitioning AP data into surface class statistics, and the RS-2 processing chain, in Sect. 3.2. In Sect. 3.3, two models for estimating $f_{\mathrm{p}}$ from $\mathrm{VV} / \mathrm{HH}$ are proposed.

Results are given in Sect. 4, beginning with a description of the evolution of dual-polarisation parameters over our study site in Sect. 4.1. A comparison of spatially distributed polarisation ratios and $f_{\mathrm{p}}$ along each AP flight line is presented in Sect. 4.2. The performance of $\mathrm{VV} / \mathrm{HH}$ models for $f_{\mathrm{p}}$ retrievals using statistics, RMSE and bias is presented in Sect. 4.3. Pertinent findings and limitations are discussed in Sect. 5, before the main results are recalled and conclusions made in Sect. 6.

\section{Stages of pond evolution}

Ponding sub-stages, describing thermodynamic (ablation) states of the ice volume (Hanesiak et al., 2001b; Perovich et al., 2007), or the evolution of surface hydrology (Eicken et al., 2002), have been identified. Eicken et al. (2002) used analyses of flow rates and transport pathways on summer FYI and MYI in the northern Chukchi Sea. These stages, hereafter the Eicken stages, are used since they provide a logical coupling between evolving surface features and dominant $\mathrm{C}$ band microwave backscatter mechanisms.
During the ponding stage I on level FYI, the melting snow cover provides a rapid influx of melt water which laterally spreads over a large area to form a high $f_{\mathrm{p}}$. The seasonal peak in $f_{\mathrm{p}}$ occurs as melt water is retained by the impermeable ice cover (see summary of published data in Polashenski et al., 2012). As there are almost no topographical controls on melt water flow, ponds spread laterally so that the $f_{\mathrm{p}}$ typically reaches $>0.5$ (Eicken et al., 2004). Ponding stage II begins when the snow cover has ablated and $f_{\mathrm{p}}$ is driven by a balance between the intensity of melt, which controls meltwater production, and lateral and vertical fluxes of meltwater, which control meltwater drainage (Eicken et al., 2002). Ponding stage III is demarcated by hydraulic connectivity between the ice and the ocean. The vertical transport of water through macroscopic holes in the ice, in addition to lateral flows, now occurs. Vertical drainage and lower $f_{\mathrm{p}}$ occurs when pond surfaces are above freeboard, and increased seawater flooding and higher $f_{\mathrm{p}}$ occurs when they reach sea level. Due to enhanced drainage, stage III is also referred to as the pond drainage stage.

\section{Methods}

\subsection{Data collection}

Data were collected during the Arctic-Ice Covered Ecosystem in a Rapidly Changing Environment (Arctic-ICE) field project from May to June 2012. Arctic-ICE is an interdisciplinary project with focus on bio-physical processes occurring at the ocean-sea ice-atmosphere interface during the spring-summer snowmelt and ponding periods. In 2012 the project was conducted on landfast FYI in the central Canadian Arctic Archipelago (CAA), adjacent to Resolute Bay, Nunavut. FYI in this region is smooth, growing thermodynamically in an approximately linear fashion until it reaches a maximum ice thickness of about $2 \mathrm{~m}$ in May (Brown and Cote, 1992). By May the mean snow thickness is approximately $20 \mathrm{~cm}$ and characterised by a brine-wetted basal layer, with salinities 1-20\%o (Brown and Cote, 1992; Barber et al., 1995; Iacozza and Barber, 2001). Snowmelt onset typically occurs in May and is followed in June to July by ponding and a rapid reduction in ice thickness before it breaks up (Hanesiak et al., 2001b). Figure 1 shows a map of the field study site location, along with the configuration of AP survey lines over the field site (hereafter Field) and Parry Sound (hereafter Parry). Also included in Fig. 1 are the outlines of the RS-2 acquisitions described below.

Proximity to Resolute Bay enabled access to an airport for AP surveys. During each survey, a set of lines were flown over Parry at an altitude of $1542 \mathrm{~m}$, followed by lines over the study site at $610 \mathrm{~m}$. Digital images of the ice surface were captured using a Canon G10 camera mounted to an open hatch in the rear of a fixed wing DHC-6 Twin Otter aircraft. The camera was operated in time-lapse mode, with 


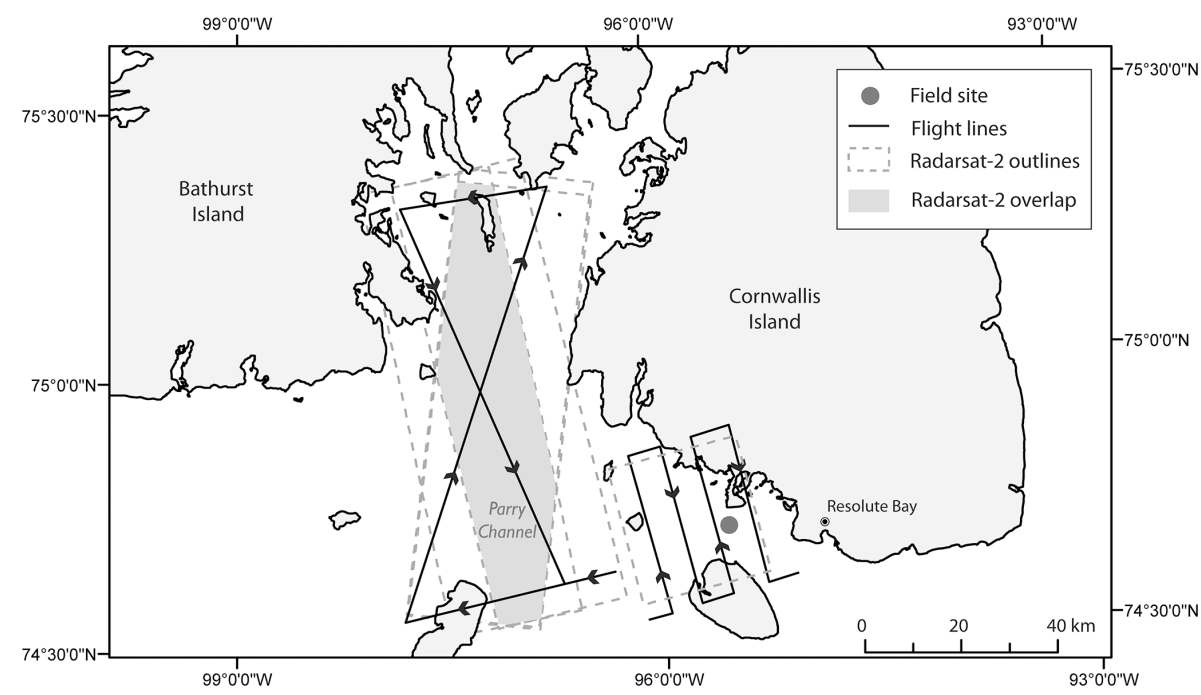

Figure 1. Map showing location of study area adjacent to the hamlet of Resolute Bay, NU, in the central Canadian Arctic Archipelago. Aerial photography flight lines over Parry and Field sites are shown along with outlines of $75 \mathrm{~km} \times 25 \mathrm{~km}$ (Parry) and $25 \mathrm{~km} \times 25 \mathrm{~km}$ (Field) Radarsat-2 scenes. The shaded region over Parry denotes the overlapping portion of scenes acquired over the site.

camera settings and capture rate controlled using a laptop and proprietary software. At $1542 \mathrm{~m}$ flying height, images cover an estimated $1872 \mathrm{~m}$ swath with $0.54 \mathrm{~m}$ pixel size; at $610 \mathrm{~m}$ flying height the swath is $749 \mathrm{~m}$ and pixel size $0.22 \mathrm{~m}$. Adjustments to the capture rate were made during flights to ensure a regular $10 \%$ image overlap, for example when ground speed or altitude variations occurred. A time-synched GPS on the aircraft was used to $\log x, y$ and $z$ position data at $1 \mathrm{~s}$ resolution for image geotagging. Data from four AP surveys are used in this study due to their temporal proximity to RS-2 overpasses. Dates, start times and identifiers for each of these flights are 13 June 2012, 22:55 UTC (AP1), 22 June 2012, 01:43 UTC (AP2), 24 June 2012, 00:08 UTC (AP3), and 29 June 2012, 14:09 UTC (AP4).

C-band frequency RS-2 SAR images were acquired in fine-beam quad-pol mode over Field and Parry. Each acquisition comprises a fully polarimetric $(\mathrm{HH}+\mathrm{VV}+\mathrm{HV}+\mathrm{VH}$ and inter-channel phase information) data set, with a nominal $5.2 \mathrm{~m} \times 7.7 \mathrm{~m}$ resolution in range and azimuth, and a $25 \mathrm{~km} \times 25 \mathrm{~km}$ image size (MDA, 2009). The absolute calibration accuracy of the quad-pol images, not provided, is typically reported to be $<1 \mathrm{~dB}$ (Luscombe, 2009). The low noise equivalent sigma zero (NESZ) of the quad-pol mode, nominally $-36.5 \pm 3 \mathrm{~dB}$, makes it an essential tool for experimental studies of low intensity targets such as level FYI. In addition, our $f_{\mathrm{p}}$ modelling approach requires acquisition of scenes at large $\theta$ resulting in low intensity backscatter. Of the 31 selectable beams available across the full $18^{\circ} \leq \theta \leq 49^{\circ}$ range available in RS-2 fine quad-pol mode, approximately the last 16 , over $35^{\circ} \leq \theta \leq 49^{\circ}$, are applicable based on results from Part 1.

RS-2 acquisitions on five different dates and over the range $41^{\circ} \leq \theta \leq 49^{\circ}$ were acquired. Over Parry three contiguous scenes in the along-track direction were acquired and later mosaicked, resulting in acquisitions covering a $25 \mathrm{~km} \times 75 \mathrm{~km}$ area. This was done on four occasions: a descending pass prior to the onset of ponds on 12 May 2012, 12:51 UTC (R1), ascending passes during ponding on 13 June 2012, 23:54 UTC (R2) and 24 June 2012, 00:02 UTC (R4), and a descending pass during late ponding on 26 June 2012, 12:51 UTC (R5). A single $25 \mathrm{~km} \times 25 \mathrm{~km}$ image during an ascending pass over Field on 20 June 2012, 23:50 UTC (R3) was acquired. Scenes R2-R5 fall within $3 \mathrm{~h}$ of an AP survey, with the exception of R3 when the gap was approximately $24 \mathrm{~h}$. We include $\mathrm{R} 1$, collected prior to ponding, in order to establish baseline quad-pol backscatter characteristics from which to assess changes associated with ponding.

Meteorological variables air temperature and $10 \mathrm{~m}$ wind speed $\left(U_{10}\right)$, and weather observations, were obtained from the WMO standard Environment Canada (EC) weather station located at Resolute Bay airport $\left(74^{\circ} 42^{\prime} 57.005^{\prime \prime} \mathrm{N}\right.$, $94^{\circ} 58^{\prime} 59.007^{\prime \prime} \mathrm{W}$ ), about $12 \mathrm{~km}$ from Field. EC data are used for assessment of general conditions associated with RS-2 acquisitions, providing consistency as overpasses extended beyond the duration of the in situ component of the study. On a case-by-case basis, hourly in situ micrometeorological data recorded at Field are used. Air temperature $\left( \pm 0.1^{\circ} \mathrm{C}\right)$ and relative humidity $( \pm 0.8 \%)$ at $2 \mathrm{~m}$ were sampled using a Rotronic Hygroclip 2 Probe. Surface skin temperature $\left( \pm 0.5^{\circ} \mathrm{C}\right)$ was measured using an Apogee SI-111 Infrared Radiometer. Incoming long-wave and short-wave radiation $( \pm 10 \%)$ were measured using a Kipp \& Zonen CNR-4 Net Radiometer. A thermistor string mounted in a melt pond provided water temperature readings at $0.5 \mathrm{~cm}$ vertical intervals. 


\subsection{Data processing}

Digital images from AP survey lines were partitioned into scenes composed of three classes: ice, melt pond and open water, using a decision-tree classification approach. This method was based on Tschudi et al. (2001), who demonstrated the effectiveness of combining the RGB-band similarities and contrasts of these features in a simple classifier. Simply, the spectral response curves of ice and open water across all RGB bands are flat, but separable in terms of magnitude, as ice is high (bright) and open water low (dark). Ponds, on the other hand, exhibit a strong contrast between red and blue channels. Decision-tree nodes corresponding to each survey line were constructed in order to account for variations in ambient lighting conditions. In some cases this was done within a single survey line. After partitioning, images from high- and low-altitude survey lines were trimmed to estimated ground coverages of $900 \mathrm{~m} \times 900 \mathrm{~m}$ and $750 \mathrm{~m} \times 750 \mathrm{~m}$, respectively, which eliminated image edges with poor radiometric resolution and improved the performance of classifiers.

A classifier performance evaluation was conducted by comparing the derived relative fractions of features from a set of partitioned scenes to fractions calculated by an expert using a manual approach. The manual approach involved using a K-means un-supervised classification algorithm and iteratively merging $n>3$ classes to $n=3$ classes using a topdown approach. Mean $f_{\mathrm{p}}$ classification error was found to be $\pm 3 \%$. A demonstration of the decision-tree classifier on a scene comprising ponds, ice and open water is given in Fig. 2.

Surface class statistics from AP1 to AP4 were each matched to SAR statistics from their spatially coincident image pairs R2-R5. A $900 \mathrm{~m} \times 900 \mathrm{~m}$ square (5625 pixel aggregate) centred on the $x, y$ position of a partitioned AP image was used to extract coincident SAR statistics for each colocated position along high altitude survey lines over Parry. A $720 \mathrm{~m} \times 720 \mathrm{~m}$ square (3600 pixel aggregate) was used for the low altitude survey over Field. To eliminate the influence of open water instead of ponds on backscatter statistics, partitioned AP images with $>1 \%$ open water were removed from the analysis. Finally, sample pairs were reduced by a factor of 2 to eliminate the potential for overlap and reduce the influence of spatial autocorrelation on the results.

RS-2 acquisitions R1-R5 were processed to calibrated and projected products including image bands of singlepolarisation VV, $\mathrm{HH}$, and $\mathrm{HV}$ backscatter, VV/HH, $\mathrm{HV} / \mathrm{HH}$ and $\theta$. Pre-processing included undersampling the raw data by a factor of 2 in range and azimuth, in order to remove correlated adjacent pixels resulting from the SAR image formation process. A $5 \times 5$ boxcar speckle filter was applied to reduce the speckle component while preserving image statistics (Oliver and Quegan, 2004). Raw data were then converted to ground range coordinates, calibrated to sigma zero, and projected to a common map projection at $12 \mathrm{~m}$ pixel spacing. This yielded an estimated 20 equivalent number

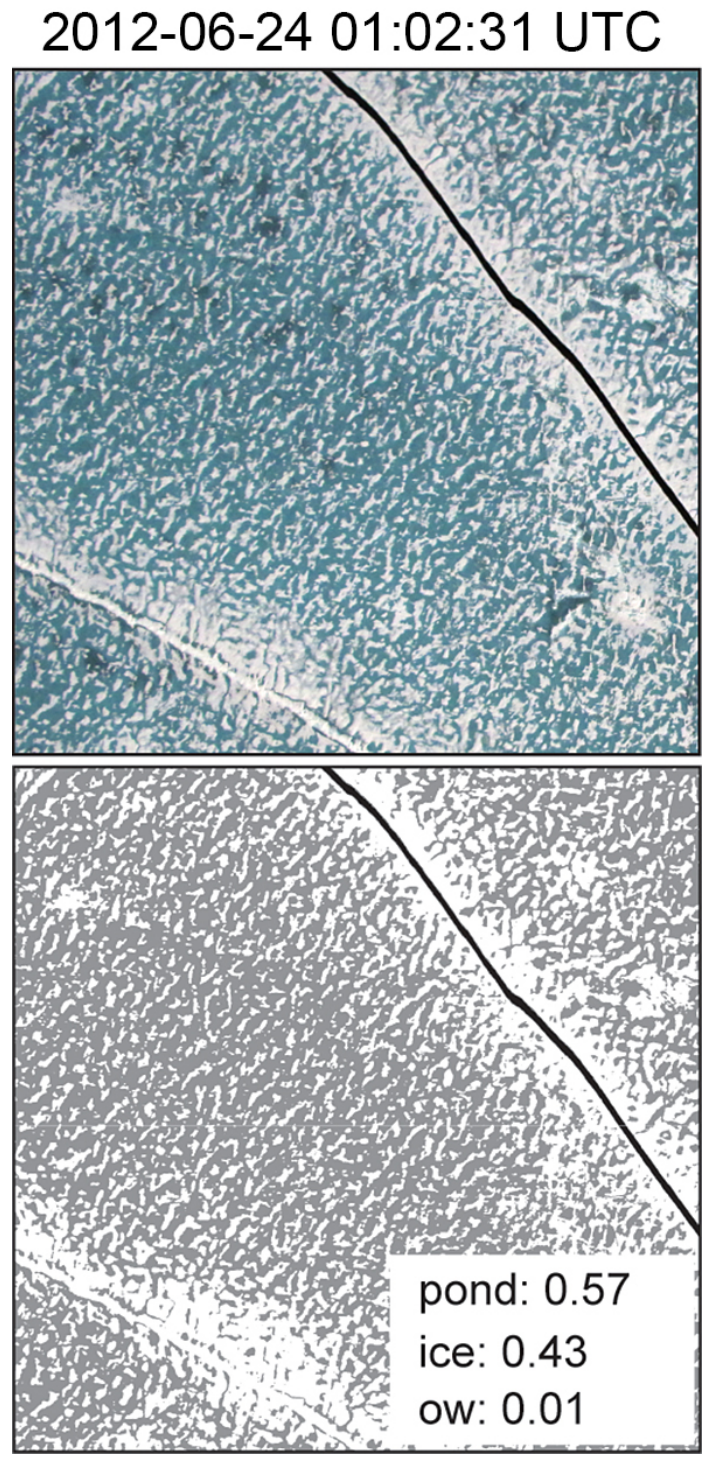

Figure 2. (Top) Sample $900 \mathrm{~m} \times 900 \mathrm{~m}$ aerial photo from Parry site on 24 June. (Bottom) Decision-tree classification result with relative fractions of ponds (grey), ice (white) and open water (black).

of looks (ENL) of a single channel at $\theta=44^{\circ}$, based on user-selected homogeneous regions of open water. Following Laur et al. (1998), the estimated radiometric resolution is expressed (in $\mathrm{dB}$ ) as

$10 \cdot \log _{10}\left(1+\frac{1}{\sqrt{\mathrm{ENL}}}\right)$,

which is $\pm 0.88 \mathrm{~dB}$ for this data set.

A correction for additive noise was applied to RS-2 data before calculating $\mathrm{VV} / \mathrm{HH}$. The method was based on Johnsen et al. (2008), who found that the subtraction of additive noise removed the saturation of $\mathrm{VV} / \mathrm{HH}$ at large $\theta$ or during low backscatter situations. A polynomial was fitted to the $\theta$ dependent additive noise level in RS-2 image 
product headers, and noise-corrected $\mathrm{VV} / \mathrm{HH}$ bands determined using

$\mathrm{VVHH}=10 \cdot \log _{10}\left[\frac{\sigma_{\mathrm{vv}}^{\circ}-\left(A \theta^{4}-B \theta^{3}+C \theta^{2}-D \theta+F\right)}{\sigma_{\mathrm{hh}}^{\circ}-\left(A \theta^{4}-B \theta^{3}+C \theta^{2}-D \theta+F\right)}\right]$,

with model coefficients A-F derived for each fine quad-pol product. The additive noise was not subtracted out of the HV and $\mathrm{HH}$ channels before calculating the $\mathrm{HV} / \mathrm{HH}$ since we found that, as did Vachon and Wolfe (2011) when comparing $\mathrm{HV} / \mathrm{HH}$ to ocean wind speed, this step did not improve subsequent correlations and information retrievals as it did for VV/HH. Finally, the World Vector Shoreline (WVS), a vector data file at a nominal scale of 1:250000 and provided by the National Oceanic and Atmospheric Administration (NOAA) National Geophysical Data Center (Soluri and Woodson, 1990), was used to mask out land within scenes.

\subsection{Proposed models}

Based on the results from in situ observations in Part 1, a model to estimate $f_{\mathrm{p}}$ from level FYI is proposed:

$f_{\mathrm{p}}=\frac{(\mathrm{VV} / \mathrm{HH})_{i}}{A[\exp (B \theta)]}$,

where subscript $i$ refers to a subscale population of ponds and bare ice patches within the SAR resolution cell collected over the range $25^{\circ} \leq \theta \leq 55^{\circ}$, and $\mathrm{VV} / \mathrm{HH}$ is in $\mathrm{dB}$. $A$ and $B$ are model coefficients fitted to scatterometer observations of ponds using a non-linear least-squares method. From Part 1 we arrived at model coefficients $A=0.3869$ and $B=0.0571$, a model regression $r^{2}=0.74$ and a standard error of $1.3 \mathrm{~dB}$. The model assumes $(\mathrm{VV} / \mathrm{HH})_{i}$ from bare ice is null, and that $(\mathrm{VV} / \mathrm{HH})_{i}$ contributions from subscale features mix linearly in the horizontal domain. Considering the radiometric resolution of $(\mathrm{VV} / \mathrm{HH})_{i}$, this noise could contribute an uncertainty in $f_{\mathrm{p}}$ estimates of \pm 0.31 to \pm 0.10 , for $\theta$ between 35 and $55^{\circ}$. We refer to the model as the C-band frequency scatterometer (Cscat) model.

Figure 3 shows Cscat modelled $f_{\mathrm{p}}$ plotted against $(\mathrm{VV} / \mathrm{HH})_{i}$ and $\theta$. From Fig. 3 conceptual relationships between radar and target parameters are illustrated. Pond information such as the formation of ponds and their evolution is more easily detected at large $\theta$ and $f_{\mathrm{p}}$, respectively. It follows that $f_{\mathrm{p}}$ may be retrieved from $(\mathrm{VV} / \mathrm{HH})_{i}$ at a fixed $\theta$, e.g. from an airborne or spaceborne $\mathrm{SAR}$, again provided the $\theta$ is large enough.

A second model was derived using a cross-validation approach. A sub-sample of the data set of RS-2 scenes and colocated AP derived $f_{\mathrm{p}}$, described in Sect. 3.2, was used to construct a predictive model:

$f_{\mathrm{p}}=0.1525 \cdot(\mathrm{VV} / \mathrm{HH})_{i}+0.1564$.

Here, $n=178$ co-located data pairs corresponding to images AP2 and AP4 were selected, and a linear least-squares fitting

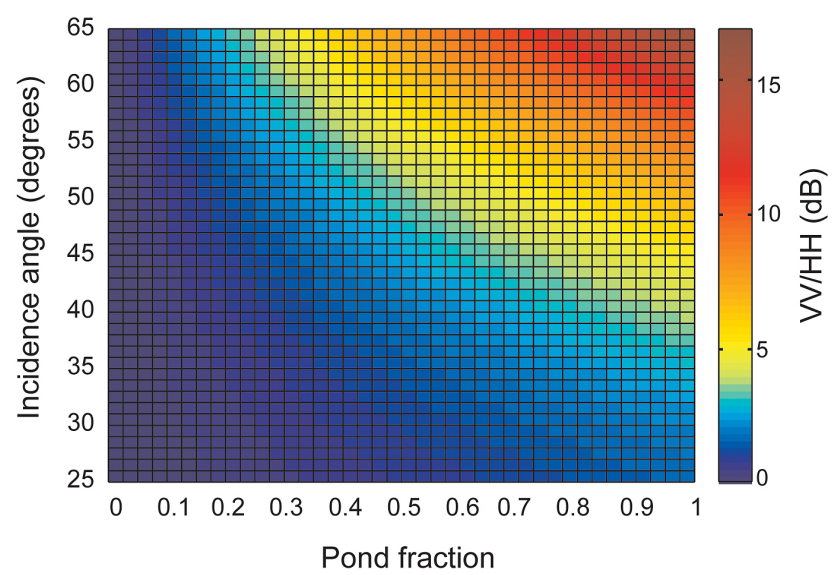

Figure 3. Illustration of Cscat modelled $\mathrm{VV} / \mathrm{HH}$ in $\mathrm{dB}$ as a function of incidence angle and pond fraction.

procedure was used to fit Eq. (4). The model regression $r^{2}=$ 0.64 , and a standard error is 0.09 . The model was derived from $f_{\mathrm{p}}$ measurements made over the range $0.08 \leq f_{\mathrm{p}} \leq 0.86$ and includes $(\mathrm{VV} / \mathrm{HH})_{i}$ measured over the range $44^{\circ} \leq \theta \leq$ $49^{\circ}$. The uncertainty of $f_{\mathrm{p}}$ when considering the radiometric resolution of $(\mathrm{VV} / \mathrm{HH})_{i}$ is \pm 0.29 . The model is hereafter called the $\mathrm{CV}$ model.

Cscat and CV models were applied to RS-2 scenes R2-R5. Model performance was assessed by deriving statistics of linear association $\left(r^{2}\right)$, bias and RMSE from co-located SAR and AP derived $f_{\mathrm{p}}$ pairs aggregated using a grid composed of $7.5 \mathrm{~km} \times 7.5 \mathrm{~km}$ cells overlaid on the study site. This aggregation scheme was chosen as it provides a good compromise between high spatial resolution RS-2 imagery and regionalscale climate models (Maslowski et al., 2011). When assessing model performance, it should be noted the CV model does not represent a true cross-validation approach. The CV model was created using co-located samples from AP2 and AP4, then applied to aggregated samples from the same data set. This introduces bias in the inversion process; however, the approach follows that used successfully to train models for wind-speed retrievals from ocean backscatter and is useful as a preliminary model performance assessment (Vachon and Wolfe, 2011).

\section{Results}

\subsection{Seasonal evolution and SAR backscatter}

RS-2 measured quad-pol parameters and coincident $f_{\mathrm{p}}$ are provided in Table 1 . Values in Table 1 for Parry represent the area of RS-2 image overlap outlined in Fig. 1. Values for Field in Table 1 represent the area within the $25 \mathrm{~km} \times 25 \mathrm{~km}$ RS-2 outline in Fig. 1. Despite too few data points from which to properly describe the seasonal 
evolution of quad-pol parameters relative to the Eicken stages, a few noteworthy generalisations are possible.

Scene R1 on 12 May was acquired about four weeks prior to ponding $\left(T_{\mathrm{a}}=-7.7^{\circ} \mathrm{C}\right)$. Intensity levels of $\mathrm{VV}, \mathrm{HH}$, $\mathrm{HV}$ and $\mathrm{VV} / \mathrm{HH}$ are lower than during ponding, except for $\mathrm{HV} / \mathrm{HH}$ which is higher. $\mathrm{VV} / \mathrm{HH}$ is close to zero $(-0.1 \mathrm{~dB})$ which is common for FYI and MYI types during cold conditions (Drinkwater et al., 1991; Nghiem and Bertoia, 2001). Scene R2 was acquired during the onset of ponding stage I as observed at Field. The coincident $f_{\mathrm{p}}=0.38$ is lower than expected for the stage I peak in this region (Yackel et al., 2000; De Abreu et al., 2001; Scharien and Yackel, 2005) and suggests this observation represents the initial stage I upturn in $f_{\mathrm{p}}$. Higher single-polarisation channel intensity for $\mathrm{R} 2$ compared to R1 is attributed to increased surface scattering caused by wind-wave roughened ponds $\left(U_{10}=11.9 \mathrm{~m} \mathrm{~s}^{-1}\right)$. The $\mathrm{VV} / \mathrm{HH}$ increase by several $\mathrm{dB}$ between $\mathrm{R} 1$ and $\mathrm{R} 2$ is consistent with the presence of melt ponds in liquid state.

Scenes R3 and R4 were acquired during ponding stage II as observed at Field. Increased $\mathrm{HH}$ and $\mathrm{HV}$ intensities, coupled with decreased $\mathrm{VV} / \mathrm{HH}$, are observed relative to R2 despite higher $\overline{f_{\mathrm{p}}}$ and lower wind stress over pond surfaces. Instead, this behaviour is better explained by the exposure of bare ice, the seasonal desalination of upper ice layers and the occurrence of volume scattering (Scharien et al., 2010).

An additional mechanism contributing to the reduction $\mathrm{VV} / \mathrm{HH}$ during $\mathrm{R} 4$, compared to $\mathrm{R} 2$ and $\mathrm{R} 3$, is the formation of ice lids on melt ponds. In Part 1, scatterometer observations showed these features have $\mathrm{VV} / \mathrm{HH}$ similar to bare ice, typically $\mathrm{VV} / \mathrm{HH} \leq 1$. Though not directly verified for the R4 acquisition over Parry, we instead use automatically logged in situ variables from Field combined with observations of both sites made during the R4 coincident AP survey. Figure 4a shows the time series evolution of air temperature $\left(T_{\mathrm{a}}\right)$, surface temperature $\left(T_{\mathrm{sfc}}\right)$ and downwelling longwave radiation $\left(Q_{\mathrm{L}}^{\downarrow}\right)$ recorded at Field over the $12 \mathrm{~h}$ period surrounding R4. Figure $4 \mathrm{~b}$ shows the vertical temperature profile of a melt pond at Field over the same interval. Until 01:00 UTC $Q_{\mathrm{L}}^{\downarrow}>300 \mathrm{~W} \mathrm{~m}^{-2}$ and the surface melting is observed, after which there is a reduction in $Q_{\mathrm{L}}^{\downarrow}$ and surface cooling. This change is consistent with the clearing of a lowlevel stratus cloud cover over Field, which we observed at approximately 00:00 UTC as part of our AP survey track. The cooling effect at Field is fully realised after about 02:00 UTC when, despite $T_{\mathrm{a}}>0{ }^{\circ} \mathrm{C}$, the entire pond is very close to, or at, its freezing point and the formation of an ice lid is likely. Since the cloud cover was tracking in a easterly direction, as identified in NOAA AVHRR (advanced very high resolution radiometer) infrared Channel 4 images checked during flight planning at Resolute airport, a similar cooling effect on Parry earlier in the day relative to Field and coincident to R4 is reasonable.

Scene R5 was acquired during the beginning of ponding stage III, the final stage before the decay and/or breakup of
FYI. Identification of this stage is based on areas of drained ice/white ice and dark thaw holes observed in AP imagery. Observations at Field were not possible and averaged quadpol parameters from Table 1 are not distinguishable from stage II.

Variations in backscatter parameters due to $\theta$ should be considered when comparing RS-2 data in Table 1 . However, isolating the variation from $\theta$ requires the heterogeneous and dynamic target parameters being imaged to be held constant between RS-2 scenes. We can investigate the impact of $\theta$ on $\mathrm{VV} / \mathrm{HH}$ from ponds using the Cscat model and input parameters from Table 1 . By increasing $\theta$ from 44 to $49^{\circ}$, we see increases from 0.6 to $0.9 \mathrm{~dB}$ at $f_{\mathrm{p}}$ of 0.38 and 0.55 , respectively.

\subsection{Spatially distributed polarisation ratios and pond fraction}

Scatter plots of polarisation ratios compared against $f_{\mathrm{p}}$ from each RS-2/AP survey pair are shown in Fig. 5. During each AP survey, a large $f_{\mathrm{p}}$ range was observed; the entire data set covers the range $0.08 \leq f_{\mathrm{p}} \leq 0.90$. Coefficients of determination $\left(r^{2}\right)$ from a linear least-squares fitting procedure between each polarisation ratio and $f_{\mathrm{p}}$ are included in each panel in Fig. 5. They are all significant at $\alpha=0.01$ except for R2. From this we can conclude a positive association between $f_{\mathrm{p}}$ and both $\mathrm{VV} / \mathrm{HH}$ and $\mathrm{HV} / \mathrm{HH}$ during ponding stages II and III.

Regarding R2 in Fig. 5, the lack of association between $\mathrm{VV} / \mathrm{HH}$ and $f_{\mathrm{p}}$ is contrary to expectation based on the Cscat model, as well as common theoretical scattering models. However, coincident $U_{10}\left(11.9 \mathrm{~m} \mathrm{~s}^{-1}\right)$ is high enough that a spatially variable wind forcing effect on $\mathrm{VV} / \mathrm{HH}$ is likely. Also, predominantly large $\mathrm{VV} / \mathrm{HH}$ (4 to $5 \mathrm{~dB}$ ) are observed even when $f_{\mathrm{p}}$ is low. Since R2 is from ponding stage $\mathrm{I}$, a mixture of slush, wet snow and bare ice patches are present within the scene. The features are likely to affect $\mathrm{VV} / \mathrm{HH}$ since variable $\varepsilon_{\mathrm{r}}$ contributions to $\mathrm{VV} / \mathrm{HH}$ from wet snow and slush, compared to bare ice, are expected (Ulaby et al., 1986). The general nature of these features were qualitatively verified at Field approximately $6 \mathrm{~h}$ prior to the AP2 survey. Remnant wet snow and slush patches were very shallow $(<3 \mathrm{~cm})$ and quantitative measurements such as moisture content could not be made.

Contrasting relationships between each polarisation ratio and $f_{\mathrm{p}}$ are observed when comparing $\mathrm{R} 3$ and $\mathrm{R} 4$ in Fig. 5. During R3, the VV/HH- $f_{\mathrm{p}}$ relationship $\left(r^{2}=0.54\right)$ is stronger than $\mathrm{HV} / \mathrm{HH}-f_{\mathrm{p}}\left(r^{2}=0.27\right)$, whereas during $\mathrm{R} 4$ the opposite occurs $\left(r^{2}=0.30\right.$ compared to $\left.r^{2}=0.54\right)$. $\mathrm{VV} / \mathrm{HH}$ during R4 is consistently low which indicates a stationary process which is damping the polarisation diversity between VV and HH. As above, we attribute this behaviour to a negative surface energy balance and the formation of ice lids on pond surfaces. Instead there is a stronger association between $\mathrm{HV} / \mathrm{HH}$ and $f_{\mathrm{p}}$ with the presence of ice lids. From 
Table 1. Radarsat-2 scene characteristics, pass (Ascending - Asc or Descending - Des) coincident hourly air temperature ( $\left.T_{\mathrm{a}}\right)$ and wind speed $\left(U_{10}\right)$ recorded at Resolute Airport, study area $f_{\mathrm{p}}$ from aerial survey data, and $\mathrm{HH}, \mathrm{VV}, \mathrm{HV}, \mathrm{VV} / \mathrm{HH}(\mathrm{Co})$ and $\mathrm{HV} / \mathrm{HH}(\mathrm{Cr})$ backscatter after SAR processing.

\begin{tabular}{lllllrrrrrrrr}
\hline ID & Site & Date and time (UTC) & Pass & $\theta^{\circ}$ & $T_{\mathrm{a}}{ }^{\circ} \mathrm{C}$ & $U_{10} \mathrm{~m} \mathrm{~s}^{-1}$ & $f_{\mathrm{p}}$ & $\mathrm{VV} \mathrm{dB}$ & $\mathrm{HH} \mathrm{dB}$ & $\mathrm{HV} \mathrm{dB}$ & $\mathrm{Co} \mathrm{dB}$ & $\mathrm{Cr} \mathrm{dB}$ \\
\hline R1 & Parry & 12 May 2012, 12:51 & Des & 49 & -7.7 & 5.6 & & -22.5 & -22.4 & -29.4 & -0.1 & -7.0 \\
R2 & Parry & 13 June 2012,23:54 & Asc & 44 & 3.9 & 11.9 & 0.38 & -16.0 & -20.1 & -28.0 & 4.1 & -7.9 \\
R3 & Field & 20 June 2012, 23:50 & Asc & 44 & 0.8 & 4.7 & 0.53 & -15.6 & -18.2 & -26.8 & 2.6 & -8.6 \\
R4 & Parry & 24 June 2012, 00:02 & Asc & 47 & 4.6 & 5.3 & 0.55 & -17.4 & -18.7 & -27.0 & 1.3 & -8.3 \\
R5 & Parry & 29 June 2012, 12:51 & Des & 49 & 5.1 & 1.1 & 0.39 & -16.7 & -18.4 & -26.5 & 1.7 & -8.1 \\
\hline
\end{tabular}

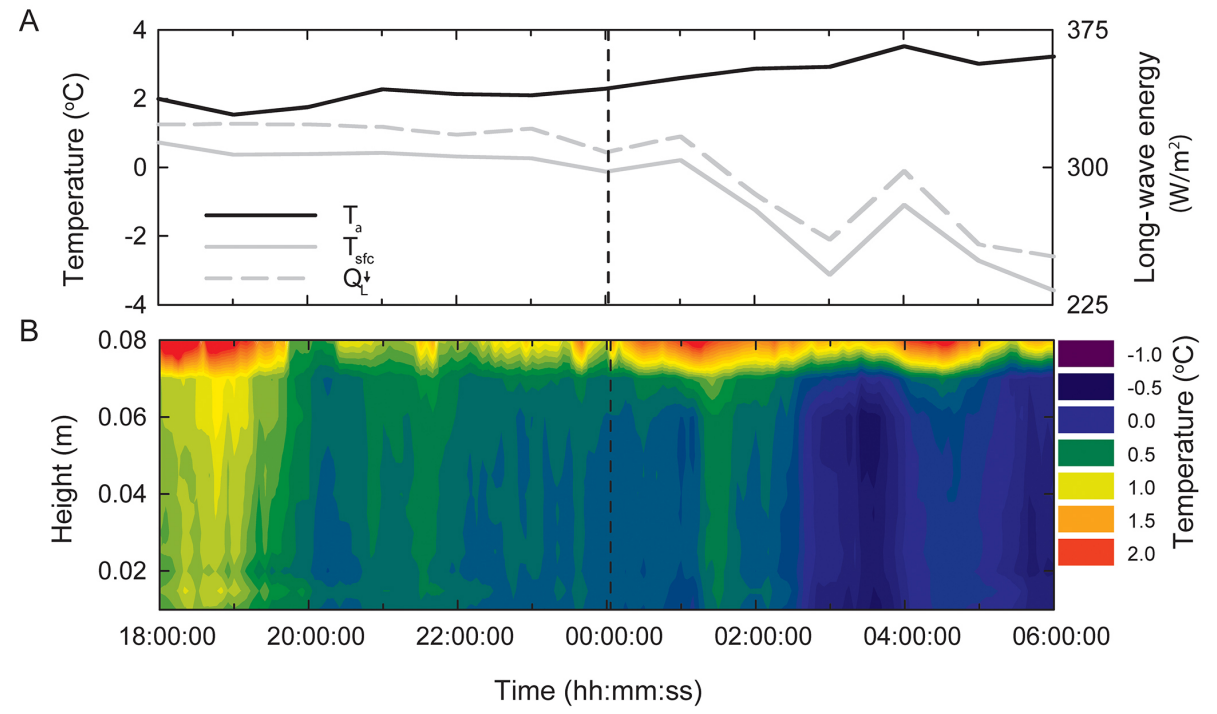

Figure 4. Meteorological variables and melt pond water temperature profile from 23 June 2012, 18:00:00 UTC to 24 June 2012, 06:00:00 UTC at the Field site, with the time of the R4 acquisition and coincident AP survey indicated by dashed vertical lines. (a) $1 \mathrm{~m}$ air temperature $\left(T_{\mathrm{a}}\right)$, surface temperature $\left(T_{\mathrm{sfc}}\right)$, and downwelling long-wave radiation $\left(Q_{\mathrm{L}}^{\downarrow}\right)$. (b) Temperature profile of a melt pond. The pond water level was recorded as $0.085 \mathrm{~m}$ before, and $0.075 \mathrm{~m}$ after, the time series. The absolute position of the air-water interface varied due to competing melt water formation and drainage processes, and surface wind-waves.

our in situ scatterometer observations in Part 1, we attribute this to a damping of $\mathrm{HH}$ compared to HV when surface windwave roughness is inhibited.

Good agreement between $\mathrm{VV} / \mathrm{HH}$ and $f_{\mathrm{p}}\left(r^{2}=0.59\right)$ is observed for R5 in Fig. 5. The lowest observed $f_{\mathrm{p}}(0.08)$ is associated with a VV/HH $\approx 0 \mathrm{~dB}$ during this stage. This indicates limited detectability of $f_{\mathrm{p}}$ below a certain threshold, here $\leq 0.08$, using $\mathrm{VV} / \mathrm{HH}$ measured across the range $44^{\circ}$ $\leq \theta \leq 49^{\circ}$. This is also qualitatively observed in the modelled data shown in Fig. 3.

We determined the signal-to-noise ratio (SNR) of the single-polarisation channels making up each polarisation ratio along the profiles in Fig. 5. Assuming a worst-case NESZ of $-33.5 \mathrm{~dB}$ for the fine quad-pol RS-2 data, we found the SNR of 4 to $9 \mathrm{~dB}$ for the lowest intensity HV channel during ponding. We also overlaid the AP4 survey locations on the R1 scene, acquired prior to ponding, to extract profile statistics similar to Fig. 5 (the orbit of R1 is similar to R5).
SNR for R1 is $3-6 \mathrm{~dB}$. Given the low intensity nature of the problem, the SNR must be considered relative to spaceborne C-band SARs that do not have the low NESZ of RS-2. Copolarisation channel intensities are approximately $-20 \mathrm{~dB}$ or better, which means $\mathrm{VV} / \mathrm{HH}$ is less likely to be problematic compared to HV/HH (see Table 1).

\subsection{Pond fraction retrievals}

The CV model was chosen for its simplicity to analyse spatial patterns of retrieved $f_{\mathrm{p}}$ from R1 to R5 (Fig. 6). Reference map information for each scene in Fig. 6 can be obtained from Fig. 1. Caution is needed when interpreting $f_{\mathrm{p}}$ from $\mathrm{R} 1$ and R2. The former occurred prior to ponding; the latter occurred during ponding stage I when no significant $\mathrm{VV} / \mathrm{HH}-$ $f_{\mathrm{p}}$ association was found. Nonetheless R1 and R2 highlight the utility of $\mathrm{VV} / \mathrm{HH}$ for detecting the onset of ponding on level FYI. Scenes R3 to R5 more closely follow the spatial and temporal evolution of $f_{\mathrm{p}}$ during ponding stages II and 

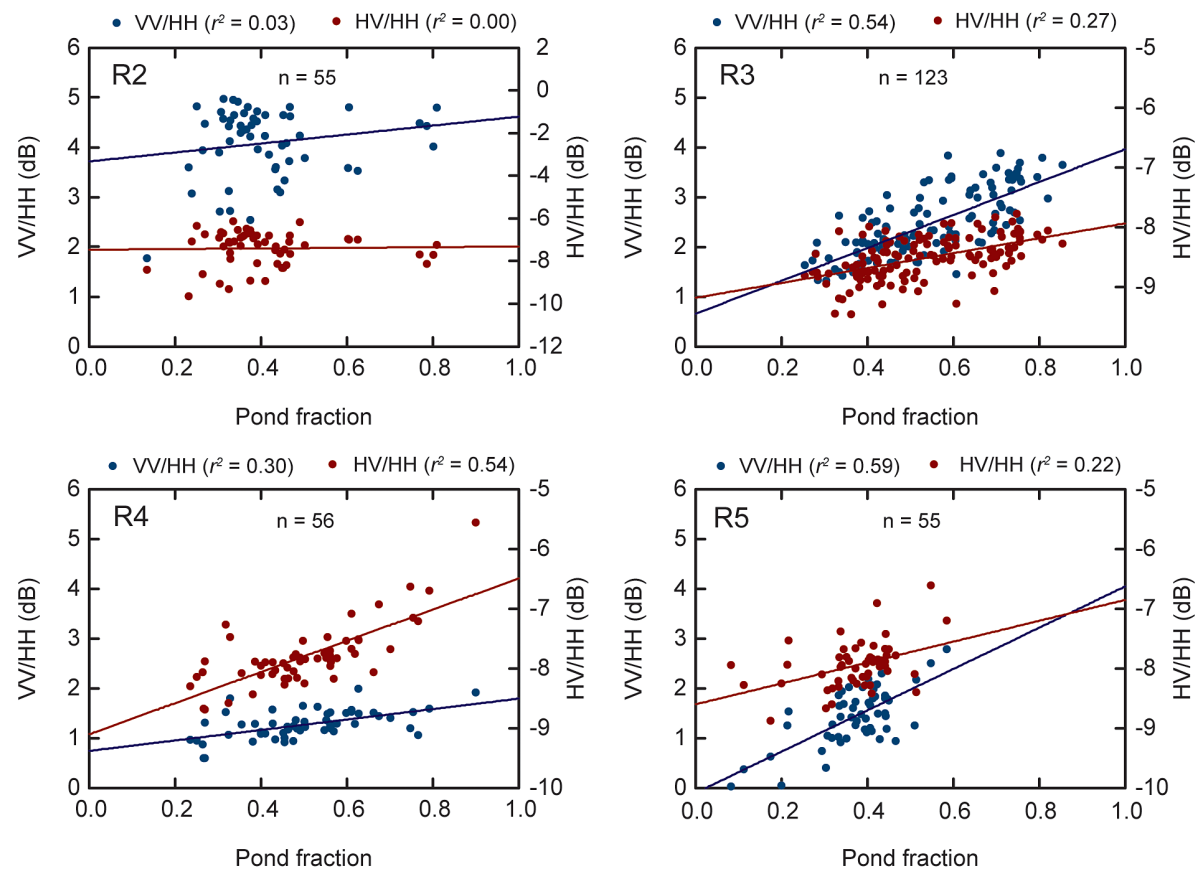

Figure 5. Scatter plots of polarimetric ratios VV/HH and HV/HH from Radarsat-2 scenes R2-R5, shown against pond fractions derived from partitioned aerial photos. Coefficients of determination between each polarimetric ratio and pond fraction are given along with the number samples in each plot.
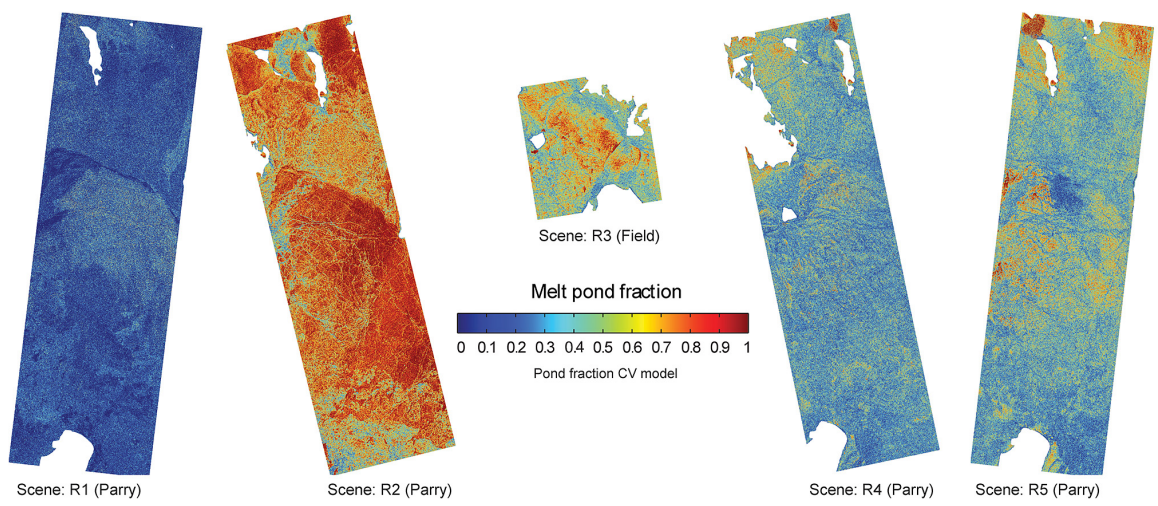

Figure 6. Retrieved pond fraction using the CV model. Refer to Fig. 1 for scale and location information, and Table 1 for scene information. White features within scenes correspond to areas of land that have been masked out. Original Radarsat-2 data ${ }^{\circledR}$ MacDONALD, DETTWILER AND ASSOCIATES LTD., 2012 All Rights Reserved.

III. A small polynya is also visible in the top portion of Parry, to the north of the elongated island, Truro Island, in scenes $\mathrm{R} 2, \mathrm{R} 4$ and R5. The open water of the polynya appears as an area with $f_{\mathrm{p}} \rightarrow 1$. Its growth from approximately $2-5 \mathrm{~km}$ in width, over the duration of the series, is apparent.

The CV model retrieval of $f_{\mathrm{p}}$ from a subset of R5 was qualitatively compared to a spatially co-located, cloud-free, Landsat-7 ETM+ scene (Fig. 7). Consistency between the two scenes is observed in the form of high and low $f_{\mathrm{p}}$ in Fig. 7a, and dark and light areas in Fig. 7b.
Deviations between AP observed and RS-2 modelled $f_{\mathrm{p}}$, using the $7.5 \mathrm{~km}$ grid cell aggregation scheme, are shown in Fig. 8. Coefficients of determination $\left(r^{2}\right)$ between observed and modelled $f_{\mathrm{p}}$, RMSE and bias are given in Table 2. A positive bias and large RMSE is evident for R2, during ponding stage I, using either Cscat or CV. This can be attributed to aforementioned uncertainty associated with high wind stress during the R2 acquisition, combined with the presence of wet snow and slush. Both CV and Cscat are much improved for R3 and R5, during melting conditions, with CV showing lower RMSE and almost no bias (Table 2). Cscat under 


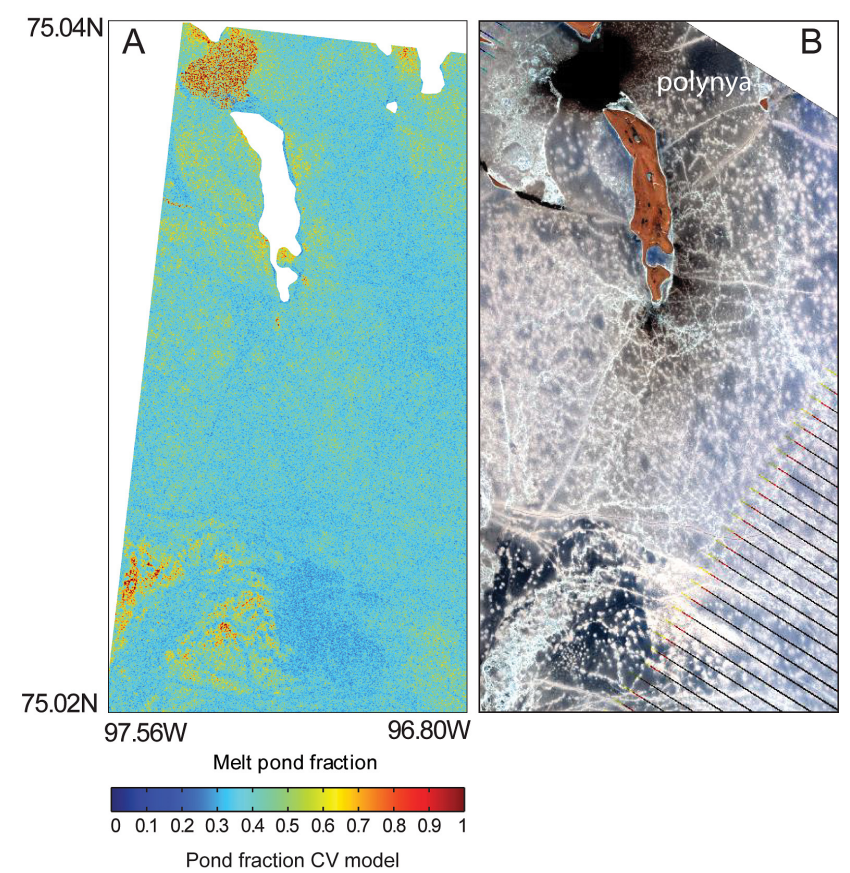

Figure 7. Comparison of pond fraction from R5 retrieved using the CV model (a) to a colour composite of a Landsat-7 ETM+ satellite image bands 4 (red), 3 (green) and 2 (blue) acquired on the same day (b). Dark lines visible in the bottom right portion of the Landsat-7 scene are due to the instrument Scan Line Corrector (SLC) failure. Original Radarsat-2 data ${ }^{\circledR}$ MacDONALD, DETTWILER AND ASSOCIATES LTD., 2012 All Rights Reserved.

Table 2. Relationships between measured and retrieved pond fraction from Radarsat-2 scenes R2 to R5.

\begin{tabular}{|c|c|c|c|c|c|c|c|}
\hline \multirow[b]{2}{*}{$\begin{array}{l}\text { RS-2 } \\
\text { Scene }\end{array}$} & \multirow[b]{2}{*}{$\begin{array}{r}\mathrm{AP} \\
\text { survey }\end{array}$} & \multirow[b]{2}{*}{$N$} & \multirow[b]{2}{*}{$r^{2}$} & \multicolumn{2}{|c|}{ Cscat model } & \multicolumn{2}{|c|}{ CV model } \\
\hline & & & & RMSE & Bias & RMSE & Bias \\
\hline R2 & $\mathrm{A} 1$ & 22 & 0.02 & 0.43 & 0.40 & 0.36 & 0.33 \\
\hline R3 & $\mathrm{A} 2$ & 15 & 0.65 & 0.06 & -0.02 & 0.05 & 0.00 \\
\hline R4 & A3 & 22 & 0.42 & 0.28 & -0.25 & 0.17 & -0.12 \\
\hline R5 & A4 & 24 & 0.55 & 0.16 & -0.15 & 0.07 & 0.01 \\
\hline
\end{tabular}

predicts $f_{\mathrm{p}}$ for R5. It is possible Cscat is affected by an enhanced damping effect on $(\mathrm{VV} / \mathrm{HH})_{i}$ caused by volume scattering from desalinated bare ice. Conversely $\mathrm{CV}$, constructed from observations which include R5, is less affected. Unfortunately in situ scatterometer or physical observations in support of this concept were not possible during ponding stage III due to the rapidly deteriorating ice conditions. Finally, neither model performs well for R4 due to freezing. The damping effect on $\mathrm{VV} / \mathrm{HH}$ caused by ice lids results in an under-prediction of $f_{\mathrm{p}}$ and large RMSE using either model.

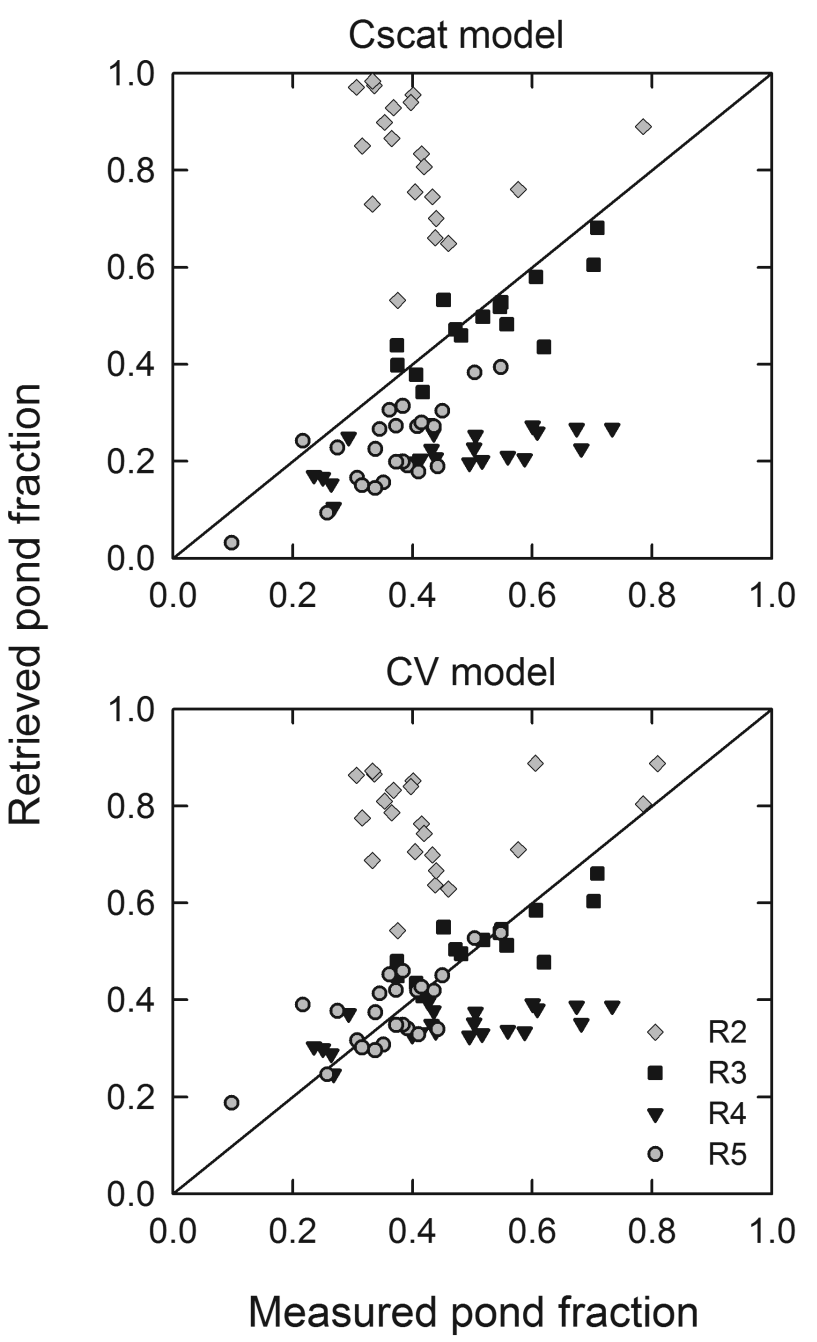

Figure 8. Comparison of pond fractions, retrieved from Radarsat-2 scenes R2-R5 using models Cscat (top) and CV (bottom), to observed pond fractions from aerial photos.

\section{Discussion}

SAR, especially at C-band frequency, will play a key role in future efforts to understand and model the Arctic environment as a complex and adaptive system at increasingly finer scales. Several missions are either operational or nearing launch. These include missions that will have multiple C-band SARs operating in constellation mode, such as ESA Sentinel-1 (Torres et al., 2012) and the Radarsat Constellation Mission or RCM (Flett et al., 2009). Sentinel-1 and $\mathrm{RCM}$ will increase the revisit frequency in polar regions to sub-daily scale, while providing wide-swath coverage. Unfortunately, Sentinel-1 will not provide the simultaneous $\mathrm{HH}$ and VV channels needed for retrievals using $\mathrm{VV} / \mathrm{HH}$, as it will acquire co- and cross-polarisation channel combinations only when operating in dual-polarisation mode. The RCM will provide simultaneous $\mathrm{HH}$ and $\mathrm{VV}$ channels in wide 
$500 \mathrm{~km}$ swath mode. C-band SARs will be complemented by SARs operating in other frequencies, e.g. L-band ALOS PalSAR-2 and X-band TerraSAR-X, as well as spaceborne scatterometers, providing greater microwave-scattering information content through diversity of frequency, $\theta$ and spatial resolution.

Limitations to the VV/HH-based retrieval models include poor performance during ponding stage I, here explained by uncertainties in $\mathrm{VV} / \mathrm{HH}$ imposed by variable pond surface roughness from wind stress, and assumed variable $\varepsilon_{\mathrm{r}}$ from wet snow and slush. More observations are required to isolate and determine the role of wind-wave roughness on $f_{\mathrm{p}}-\mathrm{VV} / \mathrm{HH}$ relationships from SAR data acquired at high wind speeds. One approach to overcome roughness limitations on measured $\mathrm{VV} / \mathrm{HH}$ is to use semi-empirical backscattering modelling, where IEM simulations are used with effective roughness parameters to separate the $s$ and $\varepsilon_{\mathrm{r}}$ contributions to $\mathrm{VV} / \mathrm{HH}$ (Zribi et al., 2006). Another approach is to adapt retrievals to lower frequencies, e.g. L- or P-bands, thereby increasing the validity range of $s$ by way of larger $k$. At frequencies lower than C-band, the enhanced role of volume-scattering bare ice would require investigation. Another limitation is the formation of ice lids on ponds during periods of negative surface energy balance, here observed during ponding stage II. In our case the ice lid formation occurred when the clearing of a low-level stratus cloud cover initiated the release of trapped long-wave radiation. This event was driven by synoptic conditions, whereas ice lid formation caused by diurnal solar minima (Yackel et al., 2007) may be more predictable in terms of acquisition planning. However, the potential utility of $\mathrm{VV} / \mathrm{HH}$ for identifying freezing events, i.e. from a damped response due to ice lids, should be considered within a time series framework.

Ultimately a VV/HH-based approach provides a logical starting point for the further development of robust models for quantitative estimations of sea ice melt pond information from SAR. The proposed models in this study are limited in their application to level FYI. Further studies are needed to determine the radar-scale roughness characteristics, and agreement between $f_{\mathrm{p}}$ and $\mathrm{VV} / \mathrm{HH}$, for rougher ice types first-year pack ice and MYI. Archived dual co-polarisation SAR imagery, such as Envisat-ASAR in alternating polarisation (AP) mode, has potential to provide multiple locations and seasons. However, a rigorous analysis of archived data is impeded by a lack of suitable in situ variables, combined with the likely absence of $f_{\mathrm{p}}$ verification data as provided here by AP surveys.

It is appropriate to acknowledge that, despite the collection of fully polarimetric data during this experiment, our objectives are defined by the need to exploit dual-polarisation C-band SAR for pond information retrievals. Polarimetry is undesirable for investigating wide-swath sea ice information retrievals since the power requirements for polarimetric sensing restricts the available swaths to $\leq 50 \mathrm{~km}$. This severely limits the satellite revisit time over a given site.

\section{Conclusions}

Methods applicable to the retrieval of climatologically and biologically significant $f_{\mathrm{p}}$ on FYI ice using satellite Cband SAR were developed from in situ observations and microwave-scattering theory (Part 1), and satellite SAR observations (this paper, Part 2). Two VV/HH-based $f_{\mathrm{p}}$ retrieval models were applied to four RS-2 acquisitions during three distinct ponding stages. Model performance was evaluated using valuable pond information derived from AP surveys. The following research questions were asked: (1) how do SAR measured C-band quad-pol backscatter parameters relate to stages of pond evolution on level FYI, and (2) can $\mathrm{C}$-band $\mathrm{VV} / \mathrm{HH}$ be used to effectively estimate $f_{\mathrm{p}}$ from level FYI?

For (1), we found a strong $\mathrm{VV} / \mathrm{HH}$ contrast between pre-ponding and ponding stage I which suggests the timing of ponding is identifiable in a seasonal series. Uncertainties regarding the relationships between surface features and backscatter behaviour during stage I require more work. A damped $\mathrm{VV} / \mathrm{HH}$ attributed to the formation of ice lids on ponds during ponding stage II suggests potential utility of $\mathrm{VV} / \mathrm{HH}$, given a priori knowledge of ponding, to identify freezing periods of climatological relevance. Good agreement is also found between $\mathrm{HV} / \mathrm{HH}$ and $f_{\mathrm{p}}$ during ponding stage II when ice lids form. For (2), the C-band VV/HH is suitable for the retrieval of $f_{\mathrm{p}}$ from level FYI at large incidence angles, here verified over the range $44^{\circ} \leq \theta \leq 49^{\circ}$, during ponding stages II and III provided ice lids are not present. Results show almost no bias using the locally derived CV model, with RMSE 0.05-0.07 comparable to $f_{\mathrm{p}}$ retrievals using contemporary optical approaches. The data presented here allow us to conclude that a C-band VV/HHbased approach for quantitative $f_{\mathrm{p}}$ retrievals from level FYI is possible within reasonable error.

The application of SAR in comprehensive EO-based sea ice process monitoring and modelling frameworks lags achievements made at the in situ scale due, in part, to uncertainties imposed by the spatial heterogeneity of sea ice, and inadequate optimisation of radar parameters such as $\theta$ and polarisation. Future work focused on the summer melt season is required (IGOS, 2007), with further studies requiring a higher density of observations, data obtained at $\theta$ down to about $35^{\circ}$ and the inclusion of several test sites covering a range of ice types or roughness classes. More work is required in order to adapt scattering models for closer agreement with radar measurements, from which robust semiempirical approaches for pond information retrievals may be established.

Acknowledgements. This paper is dedicated to our colleague Dr. Klaus Hochheim, who lost his life in September, 2013, while conducting sea ice research in the Canadian Arctic. Funding for this research was in part provided by Natural Sciences and Engineering Research Council of Canada (NSERC), the Canada Research 
Chairs and Canada Excellence Research Chairs programs. Randall Scharien is the recipient of a European Space Agency Changing Earth Science Network postdoctoral fellowship for the period 2013-2014. Thanks to John Yackel, and his students for use of their polarimetric scatterometer. Support was provided in the form of Radarsat-2 data by the Canadian Space Agency's Science and Operational Applications Research (SOAR) Program, with thanks to Stephane Chalifoux. Additional RADARAT-2 scenes were provided by the Canadian Ice Service, with thanks to Tom Zagnon and Matt Arkett. We acknowledge all participants of Arctic-ICE 2012, especially C. J. Mundy, lead investigator, and Megan Shields for assistance in the field. Gracious support for conducting aerial surveys was provided by ArcticNet and logistical support during the field campaign was provided by the Polar Continental Shelf Project (PCSP).

Edited by: D. Feltham

\section{References}

Arrigo, K. R., Perovich, D. K., Pickart, R. S., Brown, Z. W., van Dijken, G. L., Lowry, K. E., Mills, M. M., Palmer, M. A., Balch, W. M., Bahr, F., Bates, N. R., Benitez-Nelson, C., Bowler, B., Brownlee, E., Ehn, J. K., Frey, K. E., Garley, R., Laney, S. R., Lubelczyk, L., Mathis, J., Matsuoka, A., Mitchell, B. G., Moore, G. W. K., Ortega-Retuerta, E., Pal, S., Polashenski, C. M., Reynolds, R. A., Scheiber, B., Sosik, H. M., Stephens, M., and Swift, J. H.: Massive phytoplankton blooms under Arctic sea ice, Science, 336 1408, doi:10.1126/science.1215065, 2012.

Barber, D. G.: Microwave Remote Sensing, Sea Ice and Arctic Climate Processes, Physics in Canada, Sept./Oct., 61, 105-111, 2005.

Barber, D. G. and Yackel, J. J.: The physical, radiative and microwave scattering characteristics of melt ponds on Arctic landfast sea ice, Int. J. Remote Sens., 20, 2069-2090, doi:10.1080/014311699212353, 1999.

Barber, D. G., Papakyriakou, T. N., LeDrew, E. F., and Shokr, M. E.: An examination of the relation between the spring period evolution of the scattering coefficient $\left(\sigma^{\circ}\right)$ and radiative fluxes over landfast sea-ice, Int. J. Remote Sens., 16, 3343-3363, doi:10.1080/01431169508954634, 1995.

Brown, R. and Cote, P.: Interannual variability of landfast ice thickness in the Canadian high Arctic, 1950-89, Arctic, 45, 273-284, doi:10.14430/arctic1402, 1992.

Comiso, J. C., and Kwok, R.: Surface and radiative characteristics of the summer Arctic sea ice cover from multisensor satellite observations, J. Geophys. Res., 101, 28397-28416, doi:10.1029/96JC02816, 1996.

De Abreu, R., Yackel, J. J., Barber, D. G., and Arkett, M.: Operational satellite sensing of Arctic first-year sea ice melt, Can. J. Remote Sens., 27, 487-501, 2001.

Derksen, C., Piwowar J., and LeDrew, E.: Sea-ice melt-pond fraction as determined from low level aerial photographs, Arct. Alp. Res., 29, 345-351, 1997.

Drinkwater, M. R.: LIMEX' 87 Ice Surface Characteristics: Implications for C-Band SAR Backscatter Signatures, Geoscience and Remote Sensing, IEEE Trans., 27, 501-513, doi:10.1109/TGRS.1989.35933, 1989.
Drinkwater, M. R., Kwok, R., Winebrenner, D. P., and Rignot E.: Multifrequency polarimetric synthetic aperture radar observations of sea ice, J. Geophys. Res., 96, 20679-20698, doi:10.1029/91JC01915, 1991.

Ehn, J. K., Mundy, C. J., Barber, D. G., Hop, H., Rossnagel, A., and Stewart, J.: Impact of horizontal spreading on light propagation in melt pond covered seasonal sea ice in the Canadian Arctic, J. Geophys. Res., 116, C00G02, doi:10.1029/2010JC006908, 2011.

Eicken, H., Krouse, H. R., Kadko, D., and Perovich D. K.: Tracer studies of pathways and rates of meltwater transport through Arctic summer sea ice, J. Geophys. Res., 107, SHE 22-1-SHE 22-20, doi:10.1029/2000JC000583, 2002.

Eicken, H., Grenfell, T. C., Perovich, D. K., Richter-Menge, J. A., and Frey, K.: Hydraulic controls on summer Arctic pack ice albedo, J. Geophys. Res., 109, C08007, doi:10.1029/2003JC001989, 2004.

Fetterer, F. and Untersteiner N.: Observations of melt ponds on Arctic sea ice, J. Geophys. Res., 103, 24821-24835, doi:10.1029/98JC02034, 1998.

Flett, D., Crevier, Y., and Girard, R.: The RADARSAT Constellation Mission: Meeting the government of Canada's needs and requirements, Geoscience and Remote Sensing Symposium, 2009 IEEE International, IGARSS 2009, 2, II-910-II-912, doi:10.1109/IGARSS.2009.5418303, 2009.

Flocco D., Feltham, D. L., and Turner, A. K.: Incorporation of a physically-based melt pond scheme into the sea ice component of a climate model, J. Geophys. Res., 115, C08012, doi:10.1029/2009JC005568, 2010.

Freitag, J. and Eicken, H.: Meltwater circulation and permeability of Arctic summer sea ice derived from hydrological field experiments, Ann. Glaciol., 49, 349-358, 2003.

Frey, K. E., Perovich, D. K., and Light, B.: The spatial distribution of solar radiation under a melting Arctic sea ice cover, Geophys. Res. Lett., 38, L22501, doi:10.1029/2011GL049421, 2011.

Fung, A. K.: Microwave Scattering and Emission Models and Their Applications, Artech House, Inc., Norwood, Ma, 1994.

Golden, K. M., Ackley, S. F., and Lytle, V. I.: The percolation phase transition in sea ice, Science, 282, 2238-2241, doi:10.1126/science.282.5397.2238, 1998.

Hanesiak, J. M., Barber, D. G., De Abreu, R. A., and Yackel, J. J.: Local and regional albedo observations of arctic first-year sea ice during melt ponding, J. Geophys. Res., 106, 1005-1016, doi:10.1029/1999JC000068, 2001a.

Hanesiak, J. M., Yackel, J. J., and Barber, D. G.: Effect of melt ponds on first-year sea ice ablation-integration of RADARSAT1 and thermodynamic modelling, Can. J. Remote Sens., 27, 433-442, 2001b.

Heygster, G., Alexandrov, V., Dybkjær, G., von HoyningenHuene, W., Girard-Ardhuin, F., Katsev, I. L., Kokhanovsky, A., Lavergne, T., Malinka, A. V., Melsheimer, C., Toudal Pedersen, L., Prikhach, A. S., Saldo, R., Tonboe, R., Wiebe, H., and Zege, E. P.: Remote sensing of sea ice: advances during the DAMOCLES project, The Cryosphere, 6, 1411-1434, doi:10.5194/tc-61411-2012, 2012.

Holland, M. M., Bailey, D. A., Briegleb, B. P., Light, B., and Hunke, E.: Improved sea ice shortwave radiation physics in ccsm4: the impact of melt ponds and aerosols on arctic sea ice, J. Climate, 25, 1413-1430, doi:10.1175/JCLI-D-11-00078.1, 2012. 
Howell, S. E. L., Tivy, A., Yackel, J. J., and Scharien, R. K.: Application of a SeaWinds/QuikSCAT sea ice melt algorithm for assessing melt dynamics in the Canadian Arctic Archipelago, J. Geophys. Res., 111, C07025, doi:10.1029/2005JC003193, 2006.

Iacozza, J. and Barber, D. G.: Ablation patterns of snow cover over smooth first-year sea ice in the Canadian Arctic, Hydrol. Process., 15, 3359-3569, doi: 10.1002/hyp.1037, 2001.

IGOS Cryosphere: Integrated Global Observing Strategy (IGOS) cryosphere theme report, WMO/TD-No. 1405, 102 pp., 2007.

Inoue, J., Kosovic, B., and Curry, J. A.: Evolution of a storm-driven cloudy boundary layer in the Arctic, Bound.-Layer Meteor., 117, 213-230, doi:10.1007/s10546-004-6003-2, 2005.

Inoue, J., Kikuchi, T., and Perovich, D. K.: Effect of heat transmission through melt ponds and ice on melting during summer in the Arctic Ocean, J. Geophys. Res., 113, C05020, doi:10.1029/2007JC004182, 2008.

Jeffries, M. O., Schwartz, K., and Li, S.: Arctic summer sea ice SAR signatures, melt season characteristics and melt pond fractions, Polar Rec., 33, 101-112, 1997.

Johnsen, H., Engen, G., and Guitton, G.: Sea surface polarization ratio from Envisat ASAR AP data, IEEE Trans. Geosci. Remote Sens., 46, 3637-3646, doi:10.1109/TGRS.2008.2001061, 2008.

Køltzow, M.: The effect of a new snow and sea ice albedo scheme on regional climate model simulations, J. Geophys. Res., 112, D07110, doi:10.1029/2006JD007693, 2007.

Kwok, R. and Rothrock, D. A.: Decline in Arctic sea ice thickness from submarine and ICESat records: 1958-2008, Geophys. Res. Lett., 36, L15501, doi:10.1029/2009GL039035, 2009.

Kwok, R., Cunningham, G. F., Wensnahan, M., Rigor, I., Zwally, H. J., and Yi, D.: Thinning and volume loss of the Arctic Ocean sea ice cover: 2003-2008, J. Geophys. Res., 114, C07005, 2009, doi:10.1029/2009JC005312, 2009.

Laur, H., Bally, P., Meadows, P., Sanchez, J., Schaettler, B., Lopinto, E., and Esteban, D.: ESA SAR calibration: derivation of the backscattering coefficient $\sigma^{\circ}$ in ESA ERS SAR PRI products, ESA/ESRIN Technical Note, ES-TN-RS-PM-HL09, Issue 2, Rev. 5b, 1998.

Laxon, S. W., Peacock, N. R., and Smith, D. M.: High interannual variability of sea ice thickness in the Arctic region, Nature, 425, 947-950, doi:10.1038/nature02050, 2003.

Lee, S. H., Stockwell, D. A., Joo, H.-M., Son, Y. B., Kang, C.K., and Whitledge, T. E.: Phytoplankton production from melting ponds on Arctic sea ice, J. Geophys. Res., 117, C04030, doi:10.1029/2011JC007717, 2012.

Light, B., Grenfell, T. C., and Perovich, D. K.: Transmission and absorption of solar radiation by arctic sea ice during the melt season, J. Geophys. Res., 113, C03023, doi:10.1029/2006JC003977, 2008.

Livingstone, C. E., Singh, K. P., and Gray, L.: Seasonal and regional variations of active/passive microwave signatures of sea ice, Geosc. Remote Sens., IEEE Trans., GE-25, 159-173, doi:10.1109/TGRS.1987.289815, 1987.

Luscombe, A.: Image quality and calibration of RADARSAT2, Geoscience and Remote Sensing Symposium, 2009 IEEE International, IGARSS 2009, 2, II-757-II-760, doi:10.1109/IGARSS.2009.5418201, 2009.

Lüthje, M., Feltham, D. L., Taylor, P. D., and Worster, M. G.: Modelling the summertime evolution of sea-ice melt ponds, J. Geophys. Res., 111, C02001, doi:10.1029/2004JC002818, 2006.
Maslowski, W., Cassano, J., Gutowski, W., and Lettenmaier, D.: Regional Arctic Climate System Model (RACM) - Development and selected results, Geophys. Res. Abstracts, 13, EGU20119648, 2011.

Markus, T., Cavalieri, D. J., Tschudi, M. A., and Ivanoff, A.: Comparison of aerial video and Landsat 7 data over ponded sea ice, Remote Sens. Environ., 86, 458-469, doi:10.1016/S00344257(03)00124-X, 2003.

Maykut, G. A.: The ice environment, in: Sea Ice Biota, edited by: Horner, R. A., CRC Press, Boca Raton, FL, 1985.

MDA: RADARSAT-2 Product Description, RN-SP-52-1238, Issue $1 / 6,2009$.

Mundy, C. J., Gosselin, M., Ehn, J., Gratton, Y., Rossnagel, A., Barber, D. G., Martin, J., Tremblay, J.-É., Palmer, M., Arrigo, K. R., Darnis, G., Fortier, L., Else, B., and Papakyriakou, T.: Contribution of under-ice primary production to an ice-edge upwelling phytoplankton bloom in the Canadian Beaufort Sea, Geophys. Res. Lett., 36, L17601, doi:10.1029/2009GL038837, 2009.

Nghiem, S. V. and Bertoia, C.: Study of multi-polarization C-band backscatter signatures for Arctic sea ice mapping with future satellite SAR, Can. J. Remote Sens., 27, 387-402, 2001.

Oliver, C. and Quegan, S.: Understanding Synthetic Aperture Radar Images, SciTech Publishing, Raleigh, NC, 2004.

Perovich, D. K.: The optical properties of sea ice, US Army Cold Regions Research and Engineering Laboratory, Monograph 961, 33, 1996.

Perovich, D. K. and Polashenski, C.: Albedo evolution of seasonal Arctic sea ice, Geophys. Res. Lett., 39, L08501, doi:10.1029/2012GL051432, 2012.

Perovich, D. K., Roesler, C. S., and Pegau, W. S.: Variability in Arctic sea ice optical properties, J. Geophys. Res., 103, 1193-1208, doi:10.1029/97JC01614, 1998.

Perovich, D. K., Light, B., Eicken, H., Jones, K. F., Runciman, K., and Nghiem, S. V.: Increasing solar heating of the Arctic Ocean and adjacent seas, 1979-2005: Attribution and role in the ice-albedo feedback, Geophys. Res. Lett., 34, L19505, doi:10.1029/2007GL031480, 2007.

Polashenski, C., Perovich, D., and Courville, Z.: The mechanisms of sea ice melt pond formation and evolution, J. Geophys. Res., 117, C01001, doi:10.1029/2011JC007231, 2012.

Pucko, M., Stern, G. A., Barber, D., Macdonald, R. W., Warner, K., and Fuchs, C.: Mechanisms and implications of $\alpha-\mathrm{HCH}$ enrichment in melt pond water on Arctic sea ice, Environ. Sci. Technol., 46, 11862-11869, doi:10.1021/es303039f, 2012.

Rösel, A. and Kaleschke, L.: Exceptional melt pond occurrence in the years 2007 and 2011 on the Arctic sea ice revealed from MODIS satellite data, J. Geophys. Res., 117, C05018, doi:10.1029/2011JC007869, 2012.

Rösel, A., Kaleschke, L., and Birnbaum, G.: Melt ponds on Arctic sea ice determined from MODIS satellite data using an artificial neural network, The Cryosphere, 6, 431-446, doi:10.5194/tc-6431-2012, 2012.

Scharien, R. K. and Yackel, J. J.: Analysis of surface roughness and morphology of first-year sea ice melt ponds: Implications for microwave scattering, IEEE Trans. Geosci. Remote Sens., 43, 2927-2939, doi:10.1109/TGRS.2005.857896, 2005. 
Scharien, R. K., Yackel, J. J., Granskog, M. A., and Else, B. G. T.: Coincident high resolution optical-SAR image analysis for surface albedo estimation of first-year sea ice during summer melt, Remote Sens. Environ., 111, 160-171, doi:10.1016/j.rse.2006.10.025, 2007.

Scharien, R. K., Geldsetzer, T., Barber, D. G., Yackel, J. J., and Langlois, A.: Physical, dielectric, and $\mathrm{C}$ band microwave scattering properties of first-year sea ice during advanced melt, J. Geophys. Res., 115, C12026, doi:10.1029/2010JC006257, 2010.

Scharien, R. K., Yackel, J. J., Barber, D. G., Asplin, M., Gupta, M., and Isleifson, D.: Geophysical controls on $\mathrm{C}$ band polarimetric backscatter from melt pond covered Arctic first-year sea ice: Assessment using high-resolution scatterometry, J. Geophys. Res., 117, C00G18, doi:10.1029/2011JC007353, 2012.

Scharien, R. K., Landy, J., and Barber, D. G.: First-year sea ice melt pond fraction estimation from dual-polarisation C-band SAR - Part 1: In situ observations, The Cryosphere, 8, 2147-2162, doi:10.5194/tc-8-2147-2014, 2014

Skyllingstad, E. D., Paulson, C. A., and Perovich, D. K.: Simulation of melt pond evolution on level ice, J. Geophys. Res., 114, C12019, doi:10.1029/2009JC005363, 2009.

Soluri, E. A. and Woodson, V. A.: World Vector Shoreline, International Hydrographic Review, LXVII, 1990.

Taylor, P. D. and Feltham, D. L.: A model of melt pond evolution on sea ice, J. Geophys. Res., 109, C12007, doi:10.1029/2004JC002361, 2004.

Torres, R., Snoeij, P., Geudtner, D., Bibby, D., Davidson, M., Attema, E., Potin, P., Rommen, B., Floury, N., Brown, M., Navas Traver, I., Deghaye, P., Duesmann, B., Rosich, B., Miranda, N., Bruno, C., L'Abbate, M., Croci, R., Pietropaolo, A., Huchler, M., and Rostan, F.: GMES Sentinel-1 mission, Remote Sens. Environ., 120, 9-24, doi:10.1016/j.rse.2011.05.028, 2012.

Tschudi, M. A., Curry, J. A., and Maslanik, J. A.: Airborne observations of summertime surface features and their effect on surface albedo during FIRE/SHEBA, J. Geophys. Res., 106, 15335-15344, doi:10.1029/2000JD900275, 2001.

Tschudi, M. A., Maslanik, J. A., and Perovich, D. K.: Derivation of melt pond coverage on Arctic sea ice using MODIS observations, Remote Sens. Environ., 112, 2605-2614, DOI: 10.1016/j.rse.2007.12.009, 2008.

Ulaby, F. T., Moore, R. K., and Fung, A. K.: Microwave Remote Sensing: Active and Passive. From Theory to Applications, Vol. III, Artech House, Inc., Norwood, Massachusetts, 1986.
Vachon, P. W. and Wolfe, J.: C-Band cross-polarization wind speed retrieval, Geosci. Remote Sens. Lett., 8, 451-455. doi:10.1109/LGRS.2010.2085417, 2011.

Vancoppenolle, M., Meiners, K. M., Michel, C., Bopp, L., Brabant, F., Carnat, G., Delille, B., Lannuzel, D., Madec, G., Moreau, S., Tison, J.-L., and van der Merwe, P.: Role of sea ice in global biogeochemical cycles: emerging views and challenges, Quaternary Sci. Rev., 79, 207-230, doi:10.1016/j.quascirev.2013.04.011, 2013.

Winebrenner, D. P., Nelson, E. D., Colony, R., and West, R. D.: Observation of melt onset on multiyear Arctic sea ice using the ERS 1 synthetic aperture radar, J. Geophys. Res., 99, 22425-22441, doi:10.1029/94JC01268, 1994.

Yackel, J. J. and Barber, D. G.: Melt ponds on sea ice in the Canadian Archipelago 2. On the use of RADARSAT-1 synthetic aperture radar for geophysical inversion, J. Geophys. Res.-Oceans, 105, 22061-22070, doi:10.1029/2000JC900076, 2000.

Yackel, J. J., Barber, D. G., and Hanesiak, J. M.: Melt ponds on sea ice in the Canadian Archipelago 1. Variability in morphological and radiative properties, J. Geophys. Res., 105, 22049-22060, doi:10.1029/2000JC900075, 2000.

Yackel, J. J., Barber, D. G., and Papakyriakou, T. N.: On the estimation of spring melt in the North Water polynya using RADARSAT-1, Atmos.-Ocean, 39, 195-208, doi:10.1080/07055900.2001.9649676, 2001.

Yackel, J. J., Barber, D. G., Papakyriakou, T. N., and Breneman, C.: First-year sea ice spring melt transitions in the Canadian Arctic Archipelago from time-series synthetic aperture radar data, 1992-2002, Hydrol. Processes, 21, 253-265, doi:10.1002/hyp.6240, 2007.

Zege, E., Katsev, I., Malinka, A., Prikhach, A., and Heygster, G.: New approach for radiative transfer in sea ice and its application for sea ice satellite remote sensing, Radiation Processes in the Atmosphere and Ocean (IRS2012), AIP Conf. Proc. 1531, 43-46, doi:10.1063/1.4804703, 2012.

Zribi, M., Baghdadi, N., and Guerin, C.: Analysis of surface roughness heterogeneity and scattering behaviour for radar measurements, Geosci. Remote Sens., IEEE Trans., 44, 2438-2444, doi:10.1109/TGRS.2006.873742, 2006. 